\title{
At the Interface of Life and Death: Post-mortem and Other Applications of Vaginal, Skin, and Salivary Microbiome Analysis in Forensics
}

OPEN ACCESS

Edited by:

M. Eric Benbow

Michigan State University,

United States

Reviewed by:

Zachary M. Burcham,

Colorado State University,

United States

Baneshwar Singh,

Virginia Commonwealth University,

United States

*Correspondence:

Sarah Lebeer

sarah.lebeer@uantwerpen.be

Specialty section:

This article was submitted to

Systems Microbiology,

a section of the journal

Frontiers in Microbiology

Received: 13 April 2021

Accepted: 14 June 2021

Published: 28 July 2021

Citation:

Ahannach S, Spacova I,

Decorte $R$, Jehaes $E$ and Lebeer $S$

(2021) At the Interface of Life

and Death: Post-mortem and Other

Applications of Vaginal, Skin, and Salivary Microbiome Analysis

in Forensics.

Front. Microbiol. 12:694447. doi: 10.3389/fmicb.2021.694447

\author{
Sarah Ahannach', Irina Spacova1, Ronny Decorte ${ }^{2,3}$, Els Jehaes $^{4}$ and Sarah Lebeer ${ }^{1 *}$ \\ ${ }^{1}$ Department of Bioscience Engineering, Research Group Environmental Ecology and Applied Microbiology, University \\ of Antwerp, Antwerp, Belgium, ${ }^{2}$ Laboratory of Forensic Genetics, Department of Forensic Medicine, University Hospitals \\ Leuven, Leuven, Belgium, ${ }^{3}$ Department of Imaging and Pathology, Forensic Biomedical Sciences, KU Leuven, Leuven, \\ Belgium, ${ }^{4}$ Forensic DNA Laboratory, Department of Forensic Medicine, Antwerp University Hospital, Edegem, Belgium
}

Microbial forensics represents a promising tool to strengthen traditional forensic investigative methods and fill related knowledge gaps. Large-scale microbiome studies indicate that microbial fingerprinting can assist forensics in areas such as trace evidence, source tracking, geolocation, and circumstances of death. Nevertheless, the majority of forensic microbiome studies focus on soil and internal organ samples, whereas the microbiome of skin, mouth, and especially vaginal samples that are routinely collected in sexual assault and femicide cases remain underexplored. This review discusses the current and emerging insights into vaginal, skin, and salivary microbiome-modulating factors during life (e.g., lifestyle and health status) and after death (e.g., environmental influences and post-mortem interval) based on next-generation sequencing. We specifically highlight the key aspects of female reproductive tract, skin, and mouth microbiome samples relevant in forensics. To fill the current knowledge gaps, future research should focus on the degree to which the post-mortem succession rate and profiles of vaginal, skin, and saliva microbiota are sensitive to abiotic and biotic factors, presence or absence of oxygen and other gases, and the nutrient richness of the environment. Application of this microbiome-related knowledge could provide valuable complementary data to strengthen forensic cases, for example, to shed light on the circumstances surrounding death with (post-mortem) microbial fingerprinting. Overall, this review synthesizes the present knowledge and aims to provide a framework to adequately comprehend the hurdles and potential application of vaginal, skin, and salivary post-mortem microbiomes in forensic investigations.

Keywords: post-mortem microbiome, trace evidence, microbial forensics, sexual assault, femicide, nextgeneration sequencing, thanatomicrobiome, epinecrotic communities

\section{INTRODUCTION}

Violence against women is an urgent global problem, as more than one-third of women worldwide has been victim of physical and/or sexual violence in their lifetime (Devries et al., 2013; World Health Organization, 2013). Annually, 66,000 women and girls are victims of femicide, that is, intentional murder of women and girls because they are female (Geneva Declaration, 2011; 
World Health Organization and Pan American Health Organization, 2012). Remarkably, only 25\% of reported rape cases in Europe lead to a conviction, often due to the difficulty of providing evidence (Lovett and Kelly, 2009). Moreover, forensic experts are convinced that a large number of undetected homicides are misclassified in annual death statistics as natural deaths, suicides, or accidents (Karger et al., 2004; Ferguson and McKinley, 2019). The major obstacle is the difficulty of elucidating the circumstances surrounding death, including cause and manner (Pechal et al., 2018; Kaszubinski et al., 2020b). Traditional forensic techniques, such as human DNA profiling, can provide critical evidence by linking biological traces to crime scenes and individuals or through victim identification (Franzosa et al., 2015). However, they occasionally fall short because of human DNA degradation (Sijen, 2015; Ranjan and Surajit, 2018) and need to be complemented with alternative techniques.

Recent advances in microbial profiling have uncovered that each individual is home to complex microbial communities (Oh et al., 2016; Gilbert and Stephens, 2018). These communities inhabit all surfaces of the human body (for example, orogastrointestinal tract, respiratory tract, urogenital tract, skin) and collectively represent the human microbiota, with their microbial DNA signatures forming the microbiome (Ursell et al., 2012; Berg et al., 2020). Recent research suggests that the microbiome could greatly aid forensic casework (Clarke et al., 2017; Hampton-Marcell et al., 2017; Metcalf et al., 2017; Oliveira and Amorim, 2018; Bishop, 2019). For example, the microbiome can serve as a personal microbial fingerprint that not only can associate individuals to objects (Lax et al., 2015) and geographical locations that they came in contact with (Knight et al., 2016), but also can provide identifiable characteristics (Franzosa et al., 2015). Moreover, many microbial cells contain robust cell walls that leave them better protected against degradation compared to human cells (Sijen, 2015). Nevertheless, the focus of microbial forensics to date has been predominantly on gut and soil samples (Metcalf et al., 2013, Metcalf et al., 2016; Pechal et al., 2014; Javan et al., 2016b; Burcham et al., 2019; DeBruyn et al., 2021), whereas research on forensic implementation of the (post-mortem) microbiome of the female reproductive tract, skin, and oral cavity is lagging behind. Therefore, in this review, we provide a critical assessment of current research on the vaginal, skin, and oral/salivary microbiome in relation to their potential application in forensics, especially sexual assault and femicide cases.

\section{RELEVANCE OF VAGINAL, SKIN, AND SALIVARY MICROBIOME DURING LIFE FOR FORENSIC CASEWORK}

Vaginal, skin, and saliva samples represent some of the most commonly collected samples in forensic casework, including sexual assault cases (World Health Organization, 2003; Mont and White, 2007) and cases involving touch evidence (Burrill et al., 2019; Oorschot et al., 2019). These mucocutaneous niches are shaped by several microbiome-influencing factors (e.g., $\mathrm{pH}$ and oxygen) (Rojo et al., 2017; Burcham et al., 2019). However, which of these factors have the largest effect is still unknown.
Vaginal samples are routinely collected in sexual assault cases (Quaak et al., 2018; Ghemrawi et al., 2021). While their microbiome is generally neglected in forensics, the less diverse composition of vaginal microbiota, its high microbial biomass, and protected anatomical location translate into its unique potential for microbial fingerprinting (Younes et al., 2018). Depending on the women's ethnicity, the vaginal microbiome is generally dominated by Gram-positive Lactobacillus genera covered by a thick cell wall (i.e., Lactobacillus crispatus, Lactobacillus iners, Lactobacillus gasseri, and Lactobacillus jensenii) or a diverse microbiota dominated by non-lactobacilli such as Bifidobacterium, Gardnerella, Atopobium, and Prevotella (Ravel et al., 2010). Also fungal taxa mostly represented by Candida are detected, but generally in low abundances in healthy women (Chew et al., 2016). Ongoing research suggests that the vaginal microbiome composition can be correlated to individual characteristics valuable in forensics, such as health status (Ceccarani et al., 2019), ethnicity (Borgdorff et al., 2017; Gupta et al., 2017), sexual habits (Noyes et al., 2018), contraceptive use (Song et al., 2020), and pregnancy (Serrano et al., 2019), with various effect sizes that are not yet well mapped (Figure 1). For example, a longitudinal study found that sexual activity within $24 \mathrm{~h}$ of sampling has a significant negative impact on vaginal microbiome constancy as measured via the log JensenShannon divergence rate (i.e., vaginal community deviation from constancy), independent of time in the menstrual cycle (Gajer et al., 2012). The vaginal microbiome could thus represent trace evidence in sexual assault cases indicating sexual intercourse in the last $24 \mathrm{~h}$, in addition to providing links with other identifiable individual characteristics. However, whether this conclusion can be drawn from single, non-longitudinal samples after sexual intercourse needs to be investigated.

While vaginal samples are especially useful in sexual assault cases, the skin is probably the most commonly used source of forensic trace evidence, including skin under the victim's fingernails (Metcalf et al., 2017; Burrill et al., 2019). However, the unique microbial trail left behind by skin shedding (Bishop, 2019; Hampton-Marcell et al., 2020) is often overlooked. The skin microbiome is dominated by Gram-positive Staphylococcus, Corynebacterium, Cutibacterium, Streptococcus, or Micrococcus, although Gram-negative Acinetobacter are also frequently isolated (Grice and Segre, 2011). The skin microbiome composition varies depending on the body location (Costello et al., 2009; Grice and Segre, 2011), host characteristics (e.g., age, lifestyle, and cohabitation) (Ross et al., 2017), and skin care (Bouslimani et al., 2019). Importantly, the skin microbiome is at an interface between the outside world and the body that undergoes most interactions with the environment. In fact, detectable amounts of skin microbiota can be transferred to objects such as a computer keyboard and mouse (Fierer et al., 2010), shoes and phones (Lax et al., 2015), door handle, toilet seat, etc. (Flores et al., 2011). Remarkably, this is not only limited to touched surfaces, but also extends to inhabited spaces through microbial clouds which are detectable within just a few hours (Lax et al., 2014; Meadow et al., 2015). However, whether built environment microbiota can be used as trace evidence remains to be substantiated (Hampton-Marcell et al., 2020). An 
important knowledge gap is to what extent the skin microbiome can be detected on touched objects after a certain amount of time, potentially even after death. Establishing this link is complicated, as it depends on environmental parameters (e.g., temperature, moisture, and UV radiation) (Fierer et al., 2010), individual shedder status (i.e., amount of epithelium deposited on a substrate) (Lowe et al., 2002; Kanokwongnuwut et al., 2018), and surface characteristics of the object (Meadow et al., 2014).

Saliva, as the primary oral cavity sample, is another widely used trace in forensic casework, especially for skin bite marks in sexual assault and child abuse cases (Chávez-Briones et al., 2015; Leake et al., 2016). The salivary microbiome is mostly dominated by the Gram-negative Neisseria, Prevotella, or Veillonella but also contains large proportions of Gram-positive Streptococcus taxa (e.g., Streptococcus salivarius and Streptococcus oralis) (Willis et al., 2018). Oral Gram-positive bacteria have recently been described as robust markers for highly degraded saliva samples, because of their higher resistance to degradation treatment (e.g., heat denaturation, microbial decomposition, and ultraviolet irradiation) compared to Gram-negative salivary bacteria, salivary $\alpha$-amylase, and human DNA (Ohta and Sakurada, 2019). Individual characteristics that can influence the salivary microbiome composition include smoking (Belstrøm et al., 2014; Wu et al., 2016), dental hygiene (Mashima et al., 2017; Burcham et al., 2020), general and oral health (Zhou et al., 2016; Goodson et al., 2017), and socioeconomic status (Belstrøm et al., 2014; Figure 1). Importantly, shared environment at household level appears to more significantly determine the salivary microbiome than individual genetics (Shaw et al., 2017). Also intimate contact relevant in forensics, such as kissing (i.e., mixing of saliva), has been proposed to impact salivary microbial composition. Specifically, a transfer of approximately 80 million marker bacteria per intimate kiss of $10 \mathrm{~s}$ is observed, and partners have a more similar microbial community compared to unrelated

\section{PROMISING BODY SITES FOR MICROBIAL FORENSICS}

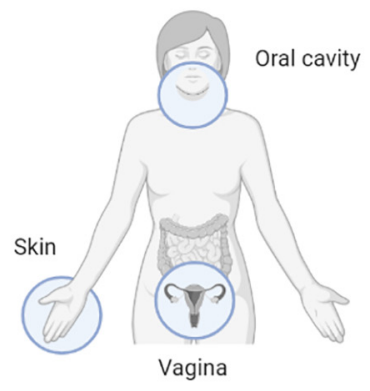

Vagina
IMPLEMENTING MICROBIOME ANALYSIS IN FORENSICS

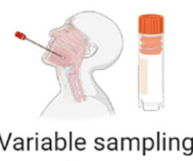
and storage

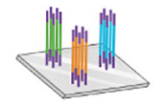

Standardizing processing and sequencing

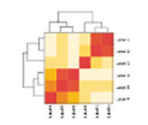

Need for larger databases with metadata

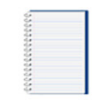

Ethics and regulations

MICROBIOME- MODULATING FACTORS IN LIFE AND DEATH

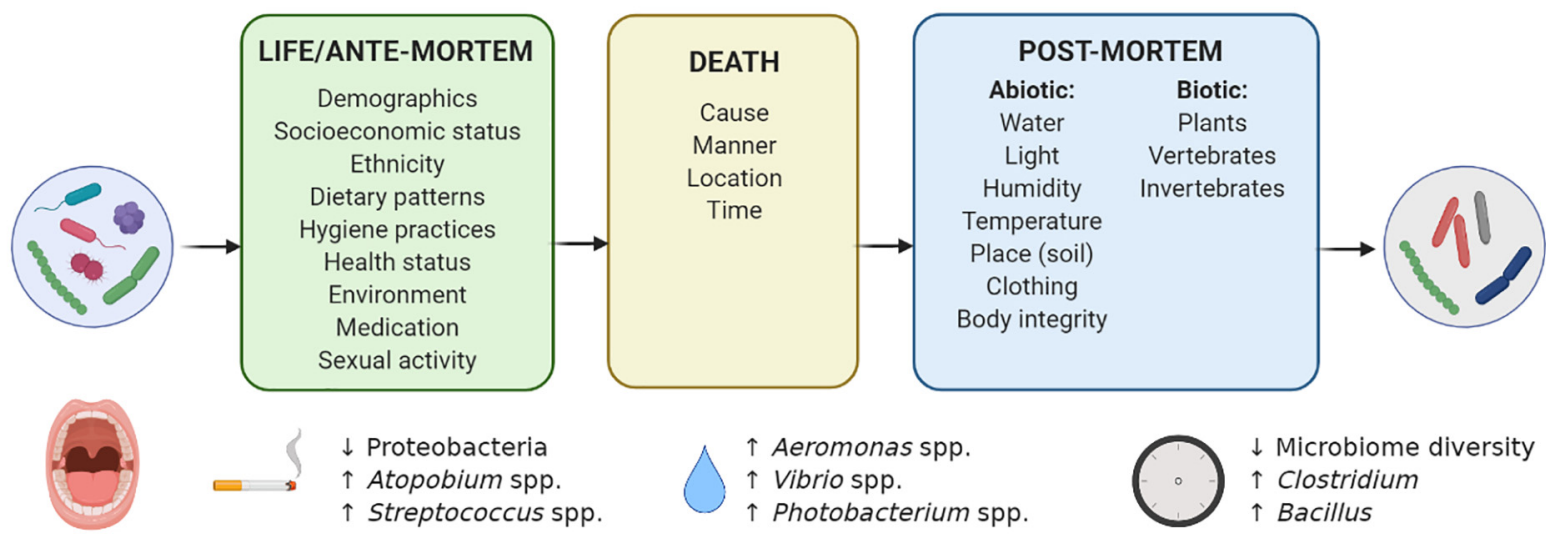

Demonstrated changes in the oral

cavity/upper respiratory tract

FIGURE 1 | Considerations for implementation of microbiome analysis in forensics and overview of factors in life and death that can influence the microbiome composition. The microbiome of the three body sites understudied in forensics (vagina, skin, and oral cavity) can be influenced by various individual factors during life, and these influences can sometimes also be detected after death. Death forms a turning point for the microbiome: the post-mortem microbiome is much more influenced by a range of environmental factors. Previously described microbiome-modulating factors in life and death are summarized, with some of the most prominent examples given of specific taxa in the oral cavity/upper respiratory tract associated with smoking during life (Wu et al., 2016), drowning as cause of death (Uchiyama et al., 2012; Benbow et al., 2015), and time that has passed since death (Adserias-Garriga et al., 2017b; Javan et al., 2017; García et al., 2020). More examples for the other body sites can be found in the text, although, to the best of our knowledge, no data are available on the post-mortem microbiome of the vagina. Implementation of microbiome analysis in forensics still requires extensive standardization of sampling and processing, as well as larger reference databases with metadata and an adjusted regulatory and ethical framework. Created with BioRender.com. 
individuals (Kort et al., 2014). Further research into factors influencing the vaginal, skin, and oral/salivary microbiomes during life will allow their more targeted implementation in forensic casework.

\section{THE DETRIMENTAL EFFECTS OF DEATH ON THE HUMAN MICROBIOME}

While the human microbiome during life is widely studied, we are just beginning to understand the post-mortem microbial community dynamics and how it can be influenced by antemortem microbial communities and modulating factors. During different stages after death, many anatomical and immunological barriers break, causing fluids, chemicals, and microorganisms that normally would not interact, to come into contact with each other (Gunn and Pitt, 2012). The post-mortem process facilitates the proliferation and relocation of microorganisms throughout the body and opens a gateway of cross-kingdom ecological interactions (Goff, 2009; García et al., 2020).

The decomposition of a human body is a continuous process caused by enzymatic reactions, (bio)chemical metabolic pathways and the activity of vertebrates and invertebrates (Pechal et al., 2018). This process is divided into a series of observable stages: fresh, active decay (including bloating and leakage of effusion), advanced decay, and dry remains/skeletonized (Goff, 2009; García et al., 2020). The course of these stages is partially determined by the diverse microbial communities occupying various internal and external body sites (Hauther et al., 2015; Javan et al., 2016a). Most studies on the post-mortem microbiome focus on estimating the minimum period of time since death [i.e., post-mortem interval (PMI)] (Goff, 2009). These studies aim to predict changes in the microbial composition of internal organs (e.g., gut, brain, liver, spleen, heart, etc.), also referred to as the post-mortem microbial clock (Metcalf et al., 2013; Finley et al., 2015).

Interestingly, studies on internal organs of mice (Metcalf et al., 2013; Burcham et al., 2019), swine (Carter et al., 2015), and human bodies (Hyde et al., 2013; Can et al., 2014; Hauther et al., 2015) have observed a shift in microbial communities from predominant aerobic microorganisms such as Staphylococcus and Enterobacteriaceae to more facultative anaerobic bacteria such as Proteobacteria, Firmicutes, and Bacteroidetes to obligate anaerobic organisms such as Clostridium, and finally sporeforming microorganisms such as Clostridium and Bacillus (Figure 1; Hyde et al., 2015; Javan et al., 2016b, 2019; García et al., 2020). According to the "post-mortem Clostridium effect," Clostridium species can be considered important drivers of this microbial shift due to their lipolytic enzymes (Janaway et al., 2009), proteolytic functions, and rapid generation time (Javan et al., 2017). However, whether the findings from studies focusing on internal organs can be extended to mucocutaneous niches entails a different narrative.

Surprisingly, to date, no post-mortem microbiome studies have examined the vaginal microbiome succession after death (Table 1). This can be explained by the limited population of decomposing human bodies (mostly white males; $>65$ years old) studied at anthropological research facilities (Pechal et al., 2018). Nevertheless, Lutz et al. (2020) found that reproductive organs (i.e., uterus and prostate) were the last internal organs to decay. Particularly, for the nulligravid uterus (i.e., never been pregnant), the post-mortem Clostridium effect was not observed in contrast to the prostate and other internal organs. Of note, during life, the uterine microbiome is distinct from the vagina with a significantly lower microbial biomass and colonization by Firmicutes, Bacteroidetes, Proteobacteria, and Actinobacteria (Garcia-grau et al., 2019), and it is not clear to what degree bacterial transfer from the vagina to the uterus occurs after death. This highlights the underexplored potential of the female reproductive tract in post-mortem research.

While current research has focused on the potential of the skin microbiome as trace evidence (Tozzo et al., 2020), to the best of our knowledge, only Kodama et al. (2019) have investigated whether actual objects from real death scenes (e.g., smoking pipes, medical devices, and phones) could be linked to the hand palm of the deceased through microbiome identification. The skin microbiome on the palm of the deceased remained stable up to $60 \mathrm{~h}$ after death, opening a window for individual microbiome identification even after death. It is noteworthy that this persistence of the skin microbiome into the early postmortem period opens the possibility of also applying the postmortem skin microbiome in PMI estimation. This is especially advantageous in cases where an autopsy is not requested, and a non-invasive microbiome sampling approach is best, because the most useful body sites for PMI estimation are external sites (e.g., skin).

Another body site easily accessible for microbiome and other sampling is the oral cavity. While its application for PMI estimation is yet to be studied in large populations, an increase of Firmicutes and Actinobacteria as the PMI increased was demonstrated (Hyde et al., 2013; Adserias-Garriga et al., 2017b). Interestingly, mouth samples pre-bloating resembled the oral microbiome during life, whereas the mouth samples post-bloating contained gut bacteria such as Tenericutes that possibly migrated from the large intestine (Adserias-Garriga et al., 2017b). Overall, studies that include more body sites, like Pechal et al. (2018) and others discussed in Table 1, could improve estimations.

The rate and pattern of decomposition are a mosaic system associated with biotic factors (e.g., individuality of the body, intrinsic and extrinsic bacteria, other microbes, and arthropods) and abiotic factors (e.g., weather, climate, humidity, and edaphic conditions) (Hyde et al., 2013; Carter et al., 2015; Newsome et al., 2021; Figure 1). It is yet to be elucidated how the contact of skin and natural body openings (mouth and vagina) with the outside environment (clothing, soil, aquatic ecosystems, etc.) can differentially influence the post-mortem body sitespecific microbiome. For the latter, the application of epinecrotic communities such as aquatic microbes on the post-mortem submersion interval estimation could be highly relevant in aquatic death investigations (Benbow et al., 2015; Cartozzo et al., 2021; Randall et al., 2021). While the exact effect sizes are rarely reported (Meurs, 2016), abiotic factors, such as insects and soils beneath a decomposing body (Cobaugh et al., 2015; 
TABLE 1 | List of human post-mortem microbiome studies which include female reproductive tract, skin and/or oral cavity samples in the last 5 years.

\begin{tabular}{|c|c|c|c|c|c|c|}
\hline Niches & Study aim & Sequencing & $\begin{array}{l}\text { Population and } \\
\text { sample size }\end{array}$ & Main outcome & Main pitfall & References \\
\hline $\begin{array}{l}\text { Brain, heart, } \\
\text { liver, spleen, } \\
\text { prostate, and } \\
\text { uterus }\end{array}$ & $\begin{array}{l}\text { Estimating } \\
\text { minimum PMI and } \\
\text { cause of death }\end{array}$ & $\begin{array}{l}16 \mathrm{~S} \text { rRNA gene } \\
\text { amplicon } \\
\text { sequencing }\end{array}$ & $\begin{array}{l}158 \text { samples } \\
40 \text { human bodies } \\
\text { (14 female, } 26 \\
\text { male) } \\
6 \text { body sites }\end{array}$ & $\begin{array}{l}\text { Reproductive } \\
\text { organs (uterus and } \\
\text { prostate) were the } \\
\text { last internal organs } \\
\text { to decay during } \\
\text { human } \\
\text { decomposition }\end{array}$ & $\begin{array}{l}\text { Larger population } \\
\text { size is needed to } \\
\text { further account for } \\
\text { variation due to } \\
\text { (a)biotic factors }\end{array}$ & Lutz et al., 2020 \\
\hline $\begin{array}{l}\text { Skin: nose and } \\
\text { ear }\end{array}$ & $\begin{array}{l}\text { Estimating } \\
\text { minimum PMI }\end{array}$ & $\begin{array}{l}16 S \text { rRNA gene } \\
\text { amplicon } \\
\text { sequencing }\end{array}$ & $\begin{array}{l}144 \text { samples } \\
21 \text { human bodies } \\
2 \text { body sites }\end{array}$ & $\begin{array}{l}\text { Machine learning } \\
\text { model predicted } \\
\text { the PMI with an } \\
\text { average error of } \\
2 \text { days }\end{array}$ & $\begin{array}{l}\text { Model was based } \\
\text { on only four human } \\
\text { bodies that were } \\
\text { sampled } \\
\text { longitudinally }\end{array}$ & $\begin{array}{l}\text { Johnson et al., } \\
2016\end{array}$ \\
\hline $\begin{array}{l}\text { Skin: left hip, } \\
\text { right hip, left } \\
\text { bicep, right } \\
\text { bicep, left } \\
\text { upper hip, right } \\
\text { upper hip, left } \\
\text { knee, groin, } \\
\text { head }\end{array}$ & $\begin{array}{l}\text { Understanding } \\
\text { microbially } \\
\text { mediated } \\
\text { processes during } \\
\text { decomposition on } \\
\text { different soil } \\
\text { substrates }\end{array}$ & $\begin{array}{l}\text { 16S rRNA gene } \\
\text { amplicon } \\
\text { sequencing } \\
\text { 18S rRNA gene } \\
\text { amplicon } \\
\text { sequencing } \\
\text { ITS amplicon } \\
\text { sequencing }\end{array}$ & $\begin{array}{l}2 \text { human bodies } \\
\text { during winter } \\
3 \text { skin sites } \\
143 \text { days } \\
2 \text { human bodies } \\
\text { during spring } \\
8 \text { skin sites } \\
82 \text { days }\end{array}$ & $\begin{array}{l}\text { Soil type was not a } \\
\text { dominant factor } \\
\text { driving community } \\
\text { development in the } \\
\text { process of } \\
\text { decomposition }\end{array}$ & $\begin{array}{l}\text { Limited population } \\
\text { size with no } \\
\text { information on sex }\end{array}$ & Metcalf et al., 2016 \\
\hline $\begin{array}{l}\text { Eyes, ears, } \\
\text { mouth, nose, } \\
\text { rectum, thigh } \\
\text { skin }\end{array}$ & $\begin{array}{l}\text { Estimating } \\
\text { minimum PMI for } \\
\text { buried bodies }\end{array}$ & $\begin{array}{l}16 S \text { rRNA gene } \\
\text { amplicon } \\
\text { sequencing }\end{array}$ & $\begin{array}{l}2 \text { male bodies } \\
10 \text { timepoints }\end{array}$ & $\begin{array}{l}\text { Multidisciplinary } \\
\text { methodology } \\
\text { identified temporal } \\
\text { changes in } \\
\text { morphology, } \\
\text { skeletal muscle } \\
\text { protein } \\
\text { decomposition, } \\
\text { entomology, and } \\
\text { microbiome for } \\
\text { buried bodies }\end{array}$ & $\begin{array}{l}\text { Model was based } \\
\text { on only two human } \\
\text { bodies of which } \\
\text { multiple samples } \\
\text { were taken }\end{array}$ & Pittner et al., 2020 \\
\hline $\begin{array}{l}\text { Skin: right } \\
\text { hand palm }\end{array}$ & $\begin{array}{l}\text { Linking objects at } \\
\text { the death scene to } \\
\text { deceased } \\
\text { individuals }\end{array}$ & $\begin{array}{l}\text { 16S rRNA gene } \\
\text { amplicon } \\
\text { sequencing }\end{array}$ & $\begin{array}{l}11 \text { male bodies } \\
5 \text { female bodies } \\
30 \text { living individuals } \\
79 \text { skin samples } \\
98 \text { object samples }\end{array}$ & $\begin{array}{l}\text { Objects could be } \\
\text { traced to deceased } \\
\text { individual } 75 \% \text { of } \\
\text { the time }\end{array}$ & $\begin{array}{l}\text { Ante-mortem } \\
\text { population was not } \\
\text { always a } \\
\text { demographic } \\
\text { representation of } \\
\text { the deceased study } \\
\text { population }\end{array}$ & $\begin{array}{l}\text { Kodama et al., } \\
2019\end{array}$ \\
\hline $\begin{array}{l}\text { Eyes, } \\
\text { nose,ears, } \\
\text { mouth, } \\
\text { umbilicus } \\
\text { rectum }\end{array}$ & $\begin{array}{l}\text { 1. Predicting the } \\
\text { ante-mortem health } \\
\text { condition of the } \\
\text { deceased } \\
\text { 2. Comparing three } \\
\text { machine learning } \\
\text { methods to predict } \\
\text { PMI, location of } \\
\text { death, and manner } \\
\text { of death } \\
\text { 3. Predicting cause } \\
\text { and manner of } \\
\text { death }\end{array}$ & $\begin{array}{l}\text { 16S rRNA gene } \\
\text { amplicon } \\
\text { sequencing }\end{array}$ & $\begin{array}{l}47 \text { male bodies } \\
141 \text { female bodies } \\
6 \text { body sites } \\
1 \text { timepoint }\end{array}$ & $\begin{array}{l}\text { 1. Microbial } \\
\text { biodiversity from } \\
\text { the mouth could } \\
\text { predict } \\
\text { ante-mortem host } \\
\text { health condition } \\
\text { (e.g., heart disease) } \\
\text { 2. Analysis of } \\
\text { post-mortem } \\
\text { microbiota from } \\
\text { more than thee } \\
\text { anatomic areas had } \\
\text { limited additional } \\
\text { value } \\
\text { 3. Beta-dispersion, } \\
\text { and case } \\
\text { demographic data } \\
\text { reflected forensic } \\
\text { death } \\
\text { determination }\end{array}$ & $\begin{array}{l}\text { Only one timepoint } \\
\text { (majority of cases } \\
\text { with estimated PMl } \\
\text { of }<72 \text { h) which } \\
\text { does not account } \\
\text { for variability within } \\
\text { a body }\end{array}$ & $\begin{array}{l}\text { 1. Pechal et al., } \\
2018 \\
\text { 2. Zhang et al., } \\
2019 \\
\text { 3. Kaszubinski } \\
\text { et al., 2020a }\end{array}$ \\
\hline
\end{tabular}


TABLE 1 | Continued

\begin{tabular}{|c|c|c|c|c|c|c|}
\hline Niches & Study aim & Sequencing & $\begin{array}{l}\text { Population and } \\
\text { sample size }\end{array}$ & Main outcome & Main pitfall & References \\
\hline $\begin{array}{l}\text { Mouth: palate, } \\
\text { tongue, inner } \\
\text { cheek mucosa } \\
\text { and tooth } \\
\text { surfaces }\end{array}$ & $\begin{array}{l}\text { Estimating } \\
\text { minimum PMI }\end{array}$ & $\begin{array}{l}16 \mathrm{~S} \text { rRNA gene } \\
\text { amplicon } \\
\text { sequencing }\end{array}$ & $\begin{array}{l}1 \text { male body } \\
2 \text { female bodies } \\
8 \text { timepoints } \\
5 \text { body sites }\end{array}$ & $\begin{array}{l}\text { Post-mortem } \\
\text { microbial } \\
\text { succession in the } \\
\text { oral cavity changed } \\
\text { in a temporal way } \\
\text { according to } \\
\text { oxygen availability }\end{array}$ & $\begin{array}{l}\text { Limited population } \\
\text { size with large } \\
\text { variability }\end{array}$ & $\begin{array}{l}\text { Adserias-Garriga } \\
\text { et al., } 2017 \mathrm{~b}\end{array}$ \\
\hline $\begin{array}{l}\text { External } \\
\text { auditory } \\
\text { canal, eyes, } \\
\text { nares, mouth, } \\
\text { umbilicus, and } \\
\text { rectum }\end{array}$ & $\begin{array}{l}\text { Studying the } \\
\text { impact of } \\
\text { coexisting } \\
\text { conditions such as } \\
\text { frozen affect the } \\
\text { human microbiome } \\
\text { at the time of } \\
\text { discovery }\end{array}$ & $\begin{array}{l}\text { 16S rRNA gene } \\
\text { amplicon } \\
\text { sequencing }\end{array}$ & $\begin{array}{l}1 \text { male body } \\
1 \text { female body } \\
3 \text { timepoints }\end{array}$ & $\begin{array}{l}\text { The microbial } \\
\text { diversity increased } \\
\text { throughout the } \\
\text { thawing process }\end{array}$ & $\begin{array}{l}\text { Association with } \\
\text { time since death or } \\
\text { cause of death }\end{array}$ & Pechal et al., 2017 \\
\hline $\begin{array}{l}\text { Blood, brain, } \\
\text { buccal cavity, } \\
\text { heart, liver, and } \\
\text { spleen }\end{array}$ & $\begin{array}{l}\text { Estimating } \\
\text { minimum PMI }\end{array}$ & $\begin{array}{l}16 \mathrm{~S} \text { rRNA gene } \\
\text { amplicon } \\
\text { sequencing }\end{array}$ & $\begin{array}{l}66 \text { samples } \\
27 \text { human bodies } \\
\text { ( } 12 \text { female, } 15 \\
\text { male) } \\
6 \text { body sites }\end{array}$ & $\begin{array}{l}\text { Microbial } \\
\text { communities } \\
\text { demonstrated } \\
\text { time-, organ-, and } \\
\text { sex-dependent } \\
\text { changes }\end{array}$ & $\begin{array}{l}\text { Niche sampling } \\
\text { was not equal for } \\
\text { all deceased } \\
\text { individuals }\end{array}$ & Javan et al., 2016b \\
\hline $\begin{array}{l}\text { Mouth, } \\
\text { external } \\
\text { left/right } \\
\text { cheeks } \\
\text { external } \\
\text { left/right bicep } \\
\text { region, torso, } \\
\text { and rectum }\end{array}$ & $\begin{array}{l}\text { Studying outdoor } \\
\text { decomposition } \\
\text { under natural } \\
\text { conditions }\end{array}$ & $\begin{array}{l}\text { 16S rRNA gene } \\
\text { amplicon } \\
\text { sequencing and } \\
454 \text { pyro- } \\
\text { sequencing }\end{array}$ & $\begin{array}{l}1 \text { male body } \\
1 \text { female body } \\
10 \text { timepoints }\end{array}$ & $\begin{array}{l}\text { Shifts in community } \\
\text { structure were } \\
\text { recorded and } \\
\text { associated with } \\
\text { major } \\
\text { decomposition and } \\
\text { related events }\end{array}$ & $\begin{array}{l}\text { Limited population } \\
\text { size with large } \\
\text { variability }\end{array}$ & Hyde et al., 2015 \\
\hline
\end{tabular}

The bold terms refer to the most relevant niches.

Metcalf et al., 2016; Adserias-Garriga et al., 2017a; Keenan et al., 2019), seasonal variation, and distinct climates (Carter et al., 2015), but also exposure and clothing (Goff, 2009), are some of the driving determinants of the microbial succession after death. Specifically, because of lack of thermoregulation, ambient temperatures (Goff, 2009) greatly affect the shift in nutrient availability and can thereby affect microbial community dynamics. Thus, while most studies have been performed in the United States (Metcalf et al., 2013; Pechal et al., 2018; DeBruyn et al., 2021) with a few in Australia, Japan, and the United Kingdom (García et al., 2020), post-mortem microbiome research in a wider range of climates should be encouraged.

\section{POTENTIAL HURDLES AND CONSIDERATIONS}

Juries in the court of law have come to rely on physical evidence to corroborate a testimony (Shelton et al., 2007). However, before microbiome research can be reliably introduced into investigative and legislative casework, it has to be peer-reviewed, standardized, and accepted by the scientific community (Kiely, 2005).

Microbiome sequencing methods can be divided into those targeting specific parts of microbial DNA, such as the widely used
16S rRNA gene amplicon sequencing, or untargeted approaches, such as metagenomic shotgun sequencing. In-depth shotgun metagenomics is relatively new and currently more expensive than 16s rRNA gene amplicon sequencing, but it offers the advantage of sequencing the whole genetic content (microbial and human) of a sample with a higher taxonomic and functional resolution (Quince et al., 2017; Schmedes et al., 2017; Hillmann et al., 2018; Walker and Datta, 2019). However, currently, amplicon sequencing is most widely implemented and thus relies on larger available datasets with metadata on microbiomemodulating factors necessary for increasing method accuracy of machine learning-based tools (Clarke et al., 2017; Belk et al., 2018; Zhang et al., 2019), allowing for larger meta-analyses (Adams et al., 2015; Wang et al., 2018). Although both methods have specific limitations regarding taxonomic resolution, limit of specificity, and artificial bias are important when analyzing different types of samples. An integrative approach using both techniques could be implemented to rapidly advance the field, although this requires higher experimental costs (Metcalf et al., 2017; Hillmann et al., 2018).

Importantly, results of microbiome studies vary due to differences in sampling, storage, processing, and data analysis (e.g., machine learning classification models) (Clarke et al., 2017; Kaszubinski et al., 2020a). Thus, while the field expands, 
forensically oriented studies should contain standardized protocols with validated techniques. These methods should ensure reproducibility, sensitivity, and quantitative accuracy while defining and delineating the limitations (e.g., expected error rates, limit of detection, and limit of specificity) (Clarke et al., 2017; Metcalf et al., 2017). Minimizing the distinct impact of these variables on microbial profiling to reduce bias and skewing of the detected microbial composition is crucial in forensic evidence.

\section{FUTURE PERSPECTIVES AND CONCLUDING REMARKS}

Microbial forensics holds much potential; however, to integrate highly dimensional microbial data into routine investigative casework, several aspects need to be clarified. A key question is to what extent and for how long various individual factors shaping the vaginal, skin, and oral/salivary microbiome during life also play a role after death. These body sites are often inhabited by Gram-positive bacteria that are potentially more resistant to environmental and temporal degradation compared to Gram-negative bacteria and human DNA. In addition, vaginal, skin, and oral/saliva samples are routinely collected as critical components of sexual assault and femicide cases. Importantly, many sensitive individual characteristics can be associated with microbiome composition; however, the magnitude of these effects requires comprehensive investigation. A better understanding of the complex human body ecosystem during life and after death is necessary with the establishment of anthropological research facilities over different continents studying diverse populations and body

\section{REFERENCES}

Adams, R. I., Bateman, A. C., Bik, H. M., and Meadow, J. F. (2015). Microbiota of the indoor environment: a meta-analysis. Microbiome 3:49. doi: 10.1186/ s40168-015-0108-103

Adserias-Garriga, J., Hernández, M., Quijada, N. M., Rodríguez Lázaro, D., Steadman, D., and Garcia-Gil, J. (2017a). Daily thanatomicrobiome changes in soil as an approach of postmortem interval estimation: an ecological perspective. Forensic Sci. Int. 278, 388-395. doi: 10.1016/j.forsciint.2017.07.017

Adserias-Garriga, J., Quijada, M., Hernandez, N. M., Rodríguez Lázaro, D., Steadman, D., and Garcia-Gil, L. J. (2017b). Dynamics of the oral microbiota as a tool to estimate time since death. Mol. Oral Microbiol. 32, 511-516. doi: 10.1111/omi.12191

Belk, A., Xu, Z. Z., Carter, D. O., Lynne, A., Bucheli, S., Knight, R., et al. (2018). Microbiome data accurately predicts the postmortem interval using random forest regression models. Genes (Basel) 9:104. doi: 10.3390/genes9020104

Belstrøm, D., Holmstrup, P., Nielsen, C. H., Kirkby, N., Heitmann, B. L., Klepacceraj, V., et al. (2014). Bacterial profiles of saliva in relation to diet, lifestyle factors, and socioeconomic status. J. Oral Microbiol. 6:10.3402/jom.v6.23609.

Benbow, M. E., Pechal, J. L., Lang, J. M., Erb, R., and Wallace, J. R. (2015). The potential of high-throughput metagenomic sequencing of aquatic bacterial communities to estimate the postmortem submersion interval. J. Forensic Sci. 60, 1500-1510. doi: 10.1111/1556-4029.12859

Berg, G., Rybakova, D., Fischer, D., Cernava, T., Vergès, M. C., Charles, T., et al. (2020). Microbiome definition re-visited: old concepts and new challenges. Microbiome 8:103. sites. Hereby, we can facilitate discoveries especially related to female health and safety by comprehending how the postmortem disturbance in the body homeostasis and its microbial communities make it more susceptible to the influences of the surrounding environment. While studies and regulations are complex specifically for the forensic field, the current and potential future possibilities of microbial forensics in phenotyping, identifying individuals, minimum PMI estimation, and the source of origin of a sample are highly important to consider and develop.

\section{AUTHOR CONTRIBUTIONS}

SA, IS, and SL conceived and designed the manuscript. SA wrote the manuscript. IS made the figure. SA, IS, RD, EJ, and SL critically reviewed the manuscript and contributed with special attention towards their specific expertise. All authors contributed to the article and approved the submitted version.

\section{ACKNOWLEDGMENTS}

We want to thank the entire research group ENdEMIC of the University of Antwerp, and the Forensic DNA Laboratories of the Antwerp University Hospital and University Hospitals of Leuven. We also want to thank the following funding agencies. SA was supported by the University Research Fund (BOF-DOCPRO 37054) of the University of Antwerp. IS was supported by the IOF-POC University of Antwerp funding ReLACT (FFI190115). SL was supported by the European Research Council (ERC) grant (Lacto-be 852600).

Bishop, A. H. (2019). The signatures of microorganisms and of human and environmental biomes can now be used to provide evidence in legal cases. FEMS Microbiol. Lett. 366:fnz021. doi: 10.1093/femsle/fnz021

Borgdorff, H., van der Veer, C., van Houdt, R., Alberts, C. J., de Vries, H. J., Bruisten, S. M., et al. (2017). The association between ethnicity and vaginal microbiota composition in Amsterdam, the Netherlands. PLoS One 12:e0181135. doi: 10.1371/journal.pone.0181135

Bouslimani, A., Silva, R., Kosciolek, T., Janssen, S., Callewaert, C., Amir, A., et al. (2019). The impact of skin care products on skin chemistry and microbiome dynamics. BMC Biol. 17:47. doi: 10.1186/s12915-019-0660-6

Burcham, Z. M., Garneau, N. L., Comstock, S. S., Tucker, R. M., Knight, R., Metcalf, J. L., et al. (2020). Patterns of oral microbiota diversity in adults and children: a crowdsourced population study. Sci. Rep. 10:2133. doi: 10.1038/s41598-02059016-59010

Burcham, Z. M., Pechal, J. L., Schmidt, C. J., Bose, J. L., Rosch, J. W., Benbow, M. E., et al. (2019). Bacterial community succession, transmigration, and differential gene transcription in a controlled vertebrate decomposition model. Front. Microbiol. 10:745. doi: 10.3389/fmicb.2019.00745

Burrill, J., Daniel, B., and Frascione, N. (2019). A review of trace "Touch DNA" deposits: variability factors and an exploration of cellular composition. Forensic Sci. Int. Genet. 39, 8-18. doi: 10.1016/j.fsigen.2018.11.019

Can, I., Javan, G. T., Pozhitkov, A. E., and Noble, P. A. (2014). Distinctive thanatomicrobiome signatures found in the blood and internal organs of humans. J. Microbiol. Methods 106, 1-7. doi: 10.1016/j.mimet.2014.07.026

Carter, D. O., Metcalf, J. L., Bibat, A., and Knight, R. (2015). Seasonal variation of postmortem microbial communities. Forensic Sci. Med. Pathol. 11, 202-207. doi: $10.1007 / \mathrm{s} 12024-015-9667-7$ 
Cartozzo, C., Simmons, T., Swall, J., and Singh, B. (2021). Postmortem submersion interval (PMSI) estimation from the microbiome of Sus scrofa bone in a freshwater river. Forensic Sci. Int. 318:110480. doi: 10.1016/j.forsciint.2020. 110480

Ceccarani, C., Foschi, C., Parolin, C., Antonietta, D. A., Gaspari, V., Consolandi, C., et al. (2019). Diversity of vaginal microbiome and metabolome during genital infections. Sci. Rep. 9:14095. doi: 10.1038/s41598-019-50410-x

Chávez-Briones, M. L., Hernández-Cortés, R., Jaramillo-Rangel, G., and OrtegaMartínez, M. (2015). Relevance of sampling and DNA extraction techniques for the analysis of salivary evidence from bite marks: a case report. Genet. Mol. Res. 14, 10165-10171.

Chew, S. Y., Thian, L., and Than, L. (2016). Vulvovaginal candidosis: contemporary challenges and the future of prophylactic and therapeutic approaches. Mycoses 56, 262-273. doi: $10.1111 /$ myc. 12455

Clarke, T. H., Gomez, A., Singh, H., Nelson, K. E., and Brinkac, L. M. (2017). Integrating the microbiome as a resource in the forensics toolkit. Forensic Sci. Int. Genet. 30, 141-147. doi: 10.1016/j.fsigen.2017.06.008

Cobaugh, K. L., Schaeffer, S. M., and Debruyn, J. M. (2015). Functional and structural succession of soil microbial communities below decomposing human cadavers. PLoS One 10:e0130201. doi: 10.1371/journal.pone.0130201

Costello, E., Lauber, C., Hamady, M., Fierer, N., Gordon, J., and Knight, R. (2009). Bacterial community variation in human body habitats across space and time. Science 326, 1694-1697. doi: 10.1126/science.1177486

DeBruyn, J. M., Hoeland, K. M., Taylor, L. S., Stevens, J. D., Moats, M. A., Bandopadhyay, S., et al. (2021). Comparative decomposition of humans and pigs: soil biogeochemistry, microbial activity and metabolomic profiles. Front. Microbiol. 11:608856. doi: 10.3389/fmicb.2020.608856

Devries, K. M., Mak, J. Y. T., García-Moreno, C., Petzold, M., Child, J. C., Falder, G., et al. (2013). The global prevalence of intimate partner violence against women. Science 340, 1527-1528. doi: 10.1126/science.1240937

Ferguson, C., and McKinley, A. (2019). Detection avoidance and mis/unclassified, unsolved homicides in Australia. J. Crim. Psychol. 10, 113-122. doi: 10.1108/ JCP-09-2019-2030

Fierer, N., Lauber, C. L., Zhou, N., Mcdonald, D., Costello, E. K., and Knight, R. (2010). Forensic identi fi cation using skin bacterial communities. Proc. Natl. Acad. Sci. U S A. 107, 6477-6481. doi: 10.1073/pnas.1000162107

Finley, S. J., Benbow, M. E., and Javan, G. T. (2015). Microbial communities associated with human decomposition and their potential use as postmortem clocks. Int. J. Legal Med. 129, 623-632. doi: 10.1007/s00414-0141059-0

Flores, G. E., Bates, S. T., Knights, D., Lauber, C. L., Stombaugh, J., Knight, R., et al. (2011). Microbial biogeography of public restroom surfaces. PLoS One 6:e28132. doi: 10.1371/journal.pone.0028132

Franzosa, E. A., Huang, K., Meadow, J. F., Gevers, D., and Lemon, K. P. (2015). Identifying personal microbiomes using metagenomic codes. Proc. Natl. Acad. Sci. U S A. 112, E2930-E2938. doi: 10.1073/pnas.1423854112

Gajer, P., Brotman, R. M., Bai, G., Sakamoto, J., Schütte, U. M. E., Zhong, X., et al. (2012). Temporal dynamics of the human vaginal microbiota. Sci. Transl. Med. 4:132ra52. doi: 10.1126/scitranslmed.3003605

García, M. G., Pérez-Cárceles, M. D., Osuna, E., and Legaz, I. (2020). Impact of the human microbiome in forensic sciences: a systematic review. Appl. Environ. Microbiol. 86:e01451-20. doi: 10.1128/AEM.01451-1420

Garcia-grau, I., Simon, C., and Moreno, I. (2019). Uterine microbiome - low biomass and high expectations. Biol. Reprod. 101, 1102-1114. doi: 10.1093/ biolre/ioy257

Geneva Declaration (2011). When the Victim Is a Woman in Global Burden of Armed Violence 2011: Lethal Encounters. Cambridge: Cambridge University Press.

Ghemrawi, M., Ramírez, A., Duncan, G., Colwell, R., Dadlani, M., and Mccord, B. (2021). The genital microbiome and its potential for detecting sexual assault. Forensic Sci. Int. Genet. 51:102432. doi: 10.1016/j.fsigen.2020.102432

Gilbert, J. A., and Stephens, B. (2018). Microbiology of the built environment. Nat. Rev. Microbiol. 16, 661-670. doi: 10.1038/s41579-018-0065-65

Goff, M. L. (2009). Early post-mortem changes and stages of decomposition in exposed cadavers. Exp. Appl. Acarol. 49, 21-36. doi: 10.1007/s10493-009-92849289

Goodson, J. M., Hartman, M., Shi, P., Hasturk, H., Yaskell, T., Vargas, J., et al. (2017). The salivary microbiome is altered in the presence of a high salivary glucose concentration. PLoS One 12:e170437. doi: 10.1371/journal. pone. 0170437

Grice, E. A., and Segre, J. A. (2011). The skin microbiome. Nat. Rev. Microbiol. 9, 244-253. doi: 10.1038/nrmicro2537

Gunn, A., and Pitt, S. J. (2012). Microbes as forensic indicators. Trop. Biomed. 29, $311-330$.

Gupta, V. K., Paul, S., and Dutta, C. (2017). Geography, ethnicity or subsistencespecific variations in human microbiome composition and diversity. Front. Microbiol. 8:1162. doi: 10.3389/fmicb.2017.01162

Hampton-Marcell, J. T., Larsen, P., Anton, T., Cralle, L., Sangwan, N., Lax, S., et al. (2020). Detecting personal microbiota signatures at artificial crime scenes. Forensic Sci. Int. 313:110351. doi: 10.1016/j.forsciint.2020.110351

Hampton-Marcell, J. T., Lopez, J. V., and Gilbert, J. A. (2017). The human microbiome: an emerging tool in forensics. Microb. Biotechnol. 10, 228-230. doi: 10.1111/1751-7915.12699

Hauther, K. A., Cobaugh, K. L., Jantz, L. M., Ph, D., Sparer, T. E., Ph, D., et al. (2015). Estimating time since death from postmortem human gut microbial communities. J. Forensic Sci. 60, 1234-1240. doi: 10.1111/1556-4029.12828

Hillmann, B., Al-ghalith, G. A., Shields-cutler, R. R., Zhu, Q., Gohl, D. M., Beckman, K. B., et al. (2018). Evaluating the information content of shallow shotgun metagenomics. mSystems 3:e00069-18.

Hyde, E. R., Haarmann, D. P., and Bucheli, S. R. (2015). Initial insights into bacterial succession during human decomposition. Int. J. Leg. Med. 129, 661671. doi: 10.1007/s00414-014-1128-1124

Hyde, E. R., Haarmann, D. P., Lynne, A. M., Bucheli, S. R., and Petrosino, J. F. (2013). The living dead: bacterial community structure of a cadaver at the onset and end of the bloat stage of decomposition. PLoS One 8:e77733. doi: 10.1371/journal.pone.0077733

Janaway, R. C., Percival, S. L., and Wilson, A. S. (2009). "Decomposition of human remains," in Microbiology and Aging: Clinical Manifestations, ed. S. L. Percival (New York, NY: Springer), 313-334. doi: 10.1007/978-1-59745-327-1_14

Javan, G. T., Finley, S. J., Abidin, Z., and Mulle, J. G. (2016a). The thanatomicrobiome: a missing piece of the microbial puzzle of death. Front. Microbiol. 7:225. doi: 10.3389/fmicb.2016.00225

Javan, G. T., Finley, S. J., Can, I., Wilkinson, J. E., Hanson, J. D., and Tarone, A. M. (2016b). Human thanatomicrobiome succession and time since death. Sci. Rep. 6:29598. doi: 10.1038/srep29598

Javan, G. T., Finley, S. J., Smith, T., Miller, J., Wilkinson, J. E., and Cevallos, M. A. (2017). Cadaver thanatomicrobiome signatures: the ubiquitous nature of clostridium species in human decomposition. Front. Microbiol. 8:2096. doi: 10.3389/fmicb.2017.02096

Javan, G. T., Finley, S. J., Tuomisto, S., Hall, A., Bendow, M. E., and Mills, D. (2019). An interdisciplinary review of the thanatomicrobiome in human decomposition. Forensic Sci. Med. Pathol. 15, 75-83. doi: 10.1007/s12024-0180061-0

Johnson, H. R., Trinidad, D. D., Guzman, S., Khan, Z., Parziale, V., Debruyn, J. M., et al. (2016). A machine learning approach for using the postmortem skin microbiome to estimate the postmortem interval. PLoS One 11:e0167370. doi: 10.1371/journal.pone.0167370

Kanokwongnuwut, P., Martin, B., Kirkbride, K. P., and Linacre, A. (2018). Shedding light on shedders. Forensic Sci. Int. Genet. 36, 20-25. doi: 10.1016/j. fsigen.2018.06.004

Karger, B., Lorin de la Grandmaison, G., Bajanowski, T., and Brinkmann, B. (2004). Analysis of 155 consecutive forensic exhumations with emphasis on undetected homicides. Int. J. Legal Med. 118, 90-94. doi: 10.1007/s00414-003-0426-z

Kaszubinski, S. F., Pechal, J. L., Schmidt, C. J., Jordan, H. R., Benbow, M. E., and Meek, M. H. (2020a). Evaluating bioinformatic pipeline performance for forensic microbiome analysis*, $\dagger$,ł. J. Forensic Sci. 65, 513-525. doi: 10.1111/ 1556-4029.14213

Kaszubinski, S. F., Pechal, J. L., Smiles, K., Schmidt, C. J., and Allen, M. S. (2020b). Dysbiosis in the dead: human postmortem microbiome beta-dispersion as an indicator of manner and cause of death. Front. Microbiol. 11:555347. doi: 10. 3389/fmicb.2020.555347

Keenan, S. W., Schaeffer, S. M., and Debruyn, J. M. (2019). Spatial changes in soil stable isotopic composition in response to carrion decomposition. Biogeosciences 16, 3929-3939. doi: 10.5194/bg-16-3929-2019

Kiely, T. F. (2005). Forensic Evidence: Science and the Criminal Law, 2nd Edition. Boca Raton, FL: CRC Press. 
Knight, R., Kelley, S. T., Siegel, J., and Gregory, J. (2016). Geography and location are the primary drivers of office microbiome composition. mSystems 1:e0002216. doi: $10.1128 / \mathrm{mSystems} .00022-16$

Kodama, W. A., Xu, Z., Metcalf, J. L., Song, S. J., Harrison, N., Knight, R., et al. (2019). Trace evidence potential in postmortem skin microbiomes: from death scene to morgue. J. Forensic Sci. 64, 791-798. doi: 10.1111/1556-4029.13949

Kort, R., Caspers, M., Graaf, A., Van De, Egmond, W., Van, et al. (2014). Shaping the oral microbiota through intimate kissing. Microbiome. 2:41.

Lax, S., Hampton-Marcell, J. T., Gibbons, S. M., Colares, G. B., Smith, D., Eisen, J. A., et al. (2015). Forensic analysis of the microbiome of phones and shoes. Microbiome 3:21. doi: 10.1186/s40168-015-0082-89

Lax, S., Smith, D. P., Hampton-Marcell, J., Owens, S. M., Handley, K. M., Scott, N. M., et al. (2014). Longitudinal analysis of microbial interaction between humans and the indoor environment. Science 345, 1048-1052. doi: 10.1126/ science. 1254529

Leake, S. L., Pagni, M., Falquet, L., Taroni, F., and Greub, G. (2016). The salivary microbiome for differentiating individuals: proof of principle. Microbes Infect. 18, 399-405. doi: 10.1016/j.micinf.2016.03.011

Lovett, J., and Kelly, L. (2009). Different Systems, Similar Outcomes? Tracking Attrition in Reported Rape Cases Across Europe. London: Child and Women Abuse Studies Unit.

Lowe, A., Murray, C., Whitaker, J., Tully, G., and Gill, P. (2002). The propensity of individuals to deposit DNA and secondary transfer of low level DNA from individuals to inert surfaces. Forensic Sci Int. 129, 25-34. doi: 10.1016/s03790738(02)00207-4

Lutz, H., Vangelatos, A., Gottel, N., Osculati, A., Visona, S., Finley, S. J., et al. (2020). Effects of extended postmortem interval on microbial communities in organs of the human cadaver. Front. Microbiol. 11:569630. doi: 10.3389/fmicb.2020. 569630

Mashima, I., Theodorea, C. F., Thaweboon, B., Thaweboon, S., Scannapieco, F. A., and Nakazawa, F. (2017). Exploring the salivary microbiome of children stratified by the oral hygiene index. PLoS One 12:e0185274. doi: 10.1371/ journal.pone. 0185274

Meadow, J. F., Altrichter, A. E., Bateman, A. C., Stenson, J., Brown, G. Z., and Green, J. L. (2015). Humans differ in their personal microbial cloud. Peer J 3:e1258. doi: 10.7717/peerj.1258

Meadow, J. F., Altrichter, A. E., Kembel, S. W., Moriyama, M., Connor, T. K. O., Womack, A. M., et al. (2014). Bacterial communities on classroom surfaces vary with human contact. Microbiome 2:7.

Metcalf, J. L., Parfrey, L. W., Gonzalez, A., Lauber, C. L., Knights, D., Ackermann, G., et al. (2013). A microbial clock provides an accurate estimate of the postmortem interval in a mouse model system. eLife 2:e01104. doi: 10.7554/ eLife.01104

Metcalf, J. L., Xu, Z. Z., Bouslimani, A., Dorrestein, P., Carter, D. O., and Knight, R. (2017). Microbiome tools for forensic science. Trends Biotechnol. 35, 814-823. doi: 10.1016/j.tibtech.2017.03.006

Metcalf, J. L., Xu, Z. Z., Weiss, S., Lax, S., Treuren, W., Van, et al. (2016). Microbial community assembly and metabolic function during mammalian corpse decomposition. Science 351, 158-162. doi: $10.1126 /$ science.aad2646

Meurs, J. (2016). The experimental design of postmortem studies: the effect size and statistical power. Forensic Sci. Med. Pathol. 12, 343-349. doi: 10.1007/s12024016-9793-x

Mont, J. D., and White, D. (2007). The Uses and Impacts of Medico-legal Evidence in Sexual Assault Cases: A Global Review. Geneva: World Health Organization.

Newsome, T. M., Barton, B., Buck, J. C., DeBruyn, J., Spencer, E., Ripple, W. J., et al. (2021). Monitoring the dead as an ecosystem indicator. Ecol. Evol. 11, 5844-5856. doi: $10.1002 /$ ece 3.7542

Noyes, N., Cho, K.-C., Ravel, J., Forney, L. J., and Abdo, Z. (2018). Associations between sexual habits, menstrual hygiene practices, demographics and the vaginal microbiome as revealed by Bayesian network analysis. PLoS One 13:e191625. doi: 10.1371/journal.pone.0191625

Oh, J., Byrd, A. L., Park, M., Kong, H. H., Segre, J. A., Oh, J., et al. (2016). Temporal stability of the human skin microbiome article temporal stability of the human skin microbiome. Cell 165, 854-866. doi: 10.1016/j.cell.2016.04.008

Ohta, J., and Sakurada, K. (2019). Oral gram-positive bacterial DNA-based identification of saliva from highly degraded samples. Forensic Sci. Int. Genet. 42, 103-112. doi: 10.1016/j.fsigen.2019.06.016
Oliveira, M., and Amorim, A. (2018). Microbial forensics: new breakthroughs and future prospects. Appl. Microbiol. Biotechnol. 102, 10377-10391. doi: 10.1007/ s00253-018-9414-9416

Oorschot, R. A. H., Van, Goray, M., Szkuta, B., Meakin, G. E., and Kokshoorn, B. (2019). DNA transfer in forensic science: a review. Forensic Sci. Int. Genet. 38, 140-166. doi: 10.1016/j.fsigen.2018.10.014

Pechal, J. L., Crippen, T. L., Benbow, M. E., Tarone, A. M., Dowd, S., and Tomberlin, J. K. (2014). The potential use of bacterial community succession in forensics as described by high throughput metagenomic sequencing. Int. J. Legal Med. 128, 193-205. doi: 10.1007/s00414-013-0872-1

Pechal, J. L., Schmidt, C. J., Jordan, H. R., and Benbow, M. E. (2017). Frozen: thawing and its effect on the postmortem microbiome in two pediatric. J. Forensic Sci. 62, 1399-1405. doi: 10.1111/1556-4029.13419

Pechal, J. L., Schmidt, C. J., Jordan, H. R., and Benbow, M. E. (2018). A largescale survey of the postmortem human microbiome, and its potential to provide insight into the living health condition. Sci. Rep. 8:5724. doi: 10.1038/s41598018-23989-w

Pittner, S., Bugelli, V., Benbow, M. E., Ehrenfellner, B., Zissler, A., Campobasso, C. P., et al. (2020). The applicability of forensic time since death estimation methods for buried bodies in advanced decomposition stages. PLoS One 15:e0243395. doi: 10.1371/journal.pone.0243395

Quaak, F. C. A., van Duijn, T., Hoogenboom, J., Kloosterman, A. D., and Kuiper, I. (2018). Human-associated microbial populations as evidence in forensic casework. Forensic Sci. Int. Genet. 36, 176-185. doi: 10.1016/j.fsigen.2018.06. 020

Quince, C., Walker, A. W., Simpson, J. T., Loman, N. J., and Segata, N. (2017). Shotgun metagenomics, from sampling to analysis. Nat. Biotechnol. 35, 833844. doi: $10.1038 /$ nbt. 3935

Randall, S., Cartozzo, C., Simmons, T., Swall, J. L., and Singh, B. (2021). Prediction of minimum postmortem submersion interval (PMSImin) based on eukaryotic community succession on skeletal remains recovered from a lentic environment. Forensic Sci. Int. 323:110784. doi: 10.1016/j.forsciint.2021.110784

Ranjan, H., and Surajit, D. (2018). Microbial degradation of forensic samples of biological origin: potential threat to human DNA typing. Mol. Biotechnol. 60, 141-153. doi: 10.1007/s12033-017-0052-55

Ravel, J., Gajer, P., Abdo, Z., Schneider, G. M., Koenig, S. S. K., Mcculle, S. L., et al. (2010). Vaginal microbiome of reproductive-age women. PNAS 108, 4680-4687.

Rojo, D., Celia, M., Raczkowska, B. A., Ferrer, M., Barbas, C., Bargiela, R., et al. (2017). Exploring the human microbiome from multiple perspectives: factors altering its composition. FEMS Microbiol. Rev. 41, 453-478. doi: 10.1093/ femsre/fuw046

Ross, A. A., Doxey, A. C., and Neufeld, J. D. (2017). The skin microbiome of cohabiting couples. mSystems 2:e00043-17. doi: 10.1128/mSystems.000 43-17

Schmedes, S. E., Woerner, A. E., and Budowle, B. (2017). Forensic human identification using skin microbiomes. Appl. Environ. Microbiol. 83:e01672-17. doi: 10.1128/AEM.01672-1617

Serrano, M. G., Parikh, H. I., Brooks, J. P., Edwards, D. J., Arodz, T. J., Edupuganti, L., et al. (2019). Racioethnic diversity in the dynamics of the vaginal microbiome during pregnancy. Nat. Med. 25, 1001-1011. doi: 10.1038/s41591-019-0465-8

Shaw, L., Ribeiro, A. L. R., Levine, A. P., and Pontikos, N. (2017). The human salivary microbiome is shaped by shared environment rather than genetics: evidence from a large family of closely related individuals. mBio 8:e01237-17. doi: 10.1128/mBio.01237-17

Shelton, H. D. E., Kim, Y. S., and Barak, G. (2007). A study of juror expectations and demands concerning scientific evidence: does the "csi effect" exist? vanderbilt. J. Entertain. Technol. Law 9, 331-368.

Sijen, T. (2015). Molecular approaches for forensic cell type identification: on mRNA, miRNA, DNA methylation and microbial markers. Forensic Sci. Int. Genet. 18, 21-32. doi: 10.1016/j.fsigen.2014.11.015

Song, S. D., Acharya, K. D., Zhu, J. E., Deveney, Christen, M., Walther-Antonio, M. R. S., et al. (2020). Daily vaginal microbiota fluctuations associated with natural hormonal cycle, contraceptives, diet, and exercise. mSphere 5:e0059320. doi: 10.1128/mSphere.00593-20

Tozzo, P., Angiolella, G. D., Brun, P., Castagliuolo, I., Gino, S., and Caenazzo, L. (2020). Skin microbiome analysis for forensic human identification: what do we know so far? Microorganisms 8:873. 
Uchiyama, T., Kakizaki, E., Kozawa, S., Nishida, S., Imamura, N., and Yukawa, N. (2012). A new molecular approach to help conclude drowning as a cause of death: simultaneous detection of eight bacterioplankton species using real-time PCR assays with TaqMan probes. Forensic Sci. Int. 222, 11-26. doi: 10.1016/j. forsciint.2012.04.029

Ursell, L. K., Metcalf, J. L., Parfrey, L. W., and Knight, R. (2012). Defining the human microbiome. Nutr. Rev. 70, 38-44. doi: 10.1111/j.1753-4887.2012. 00493.x

Walker, A. R., and Datta, S. (2019). Identification of city specific important bacterial signature for the MetaSUB CAMDA challenge microbiome data. Biol. Direct. 14:11. doi: 10.1186/s13062-019-0243-z

Wang, J., Kurilshikov, A., Radjabzadeh, D., Turpin, W., Croitoru, K., Bonder, M. J., et al. (2018). Meta-analysis of human genome-microbiome association studies: the MiBioGen consortium initiative. Microbiome 6:101.

Willis, J. R., González-Torres, P., Pittis, A. A., Bejarano, L. A., Cozzuto, L., AndreuSomavilla, N., et al. (2018). Citizen science charts two major "stomatotypes" in the oral microbiome of adolescents and reveals links with habits and drinking water composition. Microbiome 6:218. doi: 10.1186/s40168-018-0592-593

World Health Organization (2003). Guidelines for Medico-legal Care for Victims of Sexual Violence. Geneva: World Health Organization.

World Health Organization (2013). Global and Regional Estimates of Violence Against Women: Prevalence and Health Effects of Intimate Partner Violence and Non-partner Sexual Violence. Geneva: World Health Organization.

World Health Organization, and Pan American Health Organization (2012). Understanding and Addressing Violence Against Women: Femicide. Geneva: World Health Organization.

Wu, J., Peters, B. A., Dominianni, C., Zhang, Y., Pei, Z., Yang, L., et al. (2016). Cigarette smoking and the oral microbiome in a large study of American adults. ISME J. 10, 2435-2446. doi: 10.1038/ismej.2016.37
Younes, J. A., Lievens, E., Hummelen, R., van der Westen, R., Reid, G., and Petrova, M. I. (2018). Women and their microbes: the unexpected friendship. Trends Microbiol. 26, 16-32. doi: 10.1016/j.tim.2017.07.008

Zhang, Y., Id, J. L. P., Schmidt, C. J., Jordan, H. R., Wang, W., Id, M. E. B., et al. (2019). Machine learning performance in a microbial molecular autopsy context: a cross-sectional postmortem human population study. PLoS One 14:e0213829. doi: 10.1371/journal.pone.0213829

Zhou, J., Jiang, N., Wang, S., Hu, X., Jiao, K., and He, X. (2016). Exploration of human salivary microbiomes - insights into the novel characteristics of microbial community structure in caries and caries-free subjects. PLoS One 11:e0147039. doi: 10.1371/journal.pone.0147039

Conflict of Interest: The authors declare that the research was conducted in the absence of any commercial or financial relationships that could be construed as a potential conflict of interest.

Publisher's Note: All claims expressed in this article are solely those of the authors and do not necessarily represent those of their affiliated organizations, or those of the publisher, the editors and the reviewers. Any product that may be evaluated in this article, or claim that may be made by its manufacturer, is not guaranteed or endorsed by the publisher.

Copyright (c) 2021 Ahannach, Spacova, Decorte, Jehaes and Lebeer. This is an openaccess article distributed under the terms of the Creative Commons Attribution License (CC BY). The use, distribution or reproduction in other forums is permitted, provided the original author(s) and the copyright owner(s) are credited and that the original publication in this journal is cited, in accordance with accepted academic practice. No use, distribution or reproduction is permitted which does not comply with these terms. 